\title{
In Vitro Multiplication of Stevia rebaudiana (Bertoni) Genotypes by Using Different Explants
}

\author{
Fatih Seyis $^{1 *}$, Emine Yurteri ${ }^{1}$ and Aysel Özcan ${ }^{1}$ \\ ${ }^{1}$ Recep Tayyip Erdogan University, Faculty of Agronomy and Natural Sciences, Field Crops Department
}

\begin{abstract}
Stevia rebaudiana Bertoni that is a member of the Compositae family is one of the most valuable tropical medicinal plants. The origin of Stevia is South America, where it can be seen as a wild plant. Further it could be found in semi-arid habitat ranging from grassland to scrub forest to mountain terrain. Conventional cultivation or propagation methods of Stevia are as well known for time consuming, unpredictable, unreliable and less productive. Therefore, there is a crucial need to develop methods for rapid multiplication of this valuable plant. Plantlet produced through stem cutting has unstability, however the micropropagation of Stevia which may overcome some limitations associated with conventional method can be used for a rapid multiplication. Accordingly, the study results showed that different explants such as leaf, stem and root transferred to different tissue culture media for in vitro multiplication of two Stevia rebaudiana (Bertoni) genotypes could be reproduced by using different explants.
\end{abstract}

Key words: Stevia rebaudiana, tissue culture, multiplication, in vitro, genotype, explant

\section{INTRODUCTION}

The sweet plant Stevia rebaudiana Bertoni is native to Paraguay and widespread in this region. The natural habitat of Stevia rebaudiana is subtropical grasslands (mesothermalhumid climatic zone) of the mountain range of North-Eastern Paraguay at altitudes of about $200-600 \mathrm{~m}$ above sea level, in the Amambay Cordillera (Katayama et al., 1976). As mentioned by Kinghorn (2002) it usually grows in semidry mountainous terrains, and its habitat ranges from grasslands, scrub forests, forested mountain slopes and conifer forests to subalpine vegetation.

Stevia (S. rebaudiana Bertoni) is a noncaloric natural-source alternative to artificially produced sugar substitutes. The sweet compounds pass through the digestive process without chemically breaking down, making stevia safe for those who need to control their blood sugar level (Strauss, 1995). There have been no reports investigating adverse effects from the use of stevia products by humans (Brandle and Rosa, 1992).
Germplasm of Stevia exhibits very poor germination (Debnath et al., 2008). Moreover, population raised from seeds resulted in variability in the major characteristic of Stevia i.e., Stevioside and its percentage. Vegetative propagation is very low in number of individuals that can be obtained from single plant (Yang et al., 1981). Keeping these difficulties in mind; tissue culture is the only technique through which one can obtain mass propagation of Stevia plants with homogeneous population. Protocols for propagation of sweet herb from leaf, nodal and axillary shoot explants are established (Yang et al., 1981; Lu, 1993). Ghuari et al. (2009) reported the micro propagation from apical meristem and nodal segment.

Recent reports have shown that plant population produced by direct organogenesis from shoot meristem and leaf explants are homogenous (Tamura et al., 1984a; Miyagawa and Fujioka, 1986). Therefore, genetically identical plants could be provided via regeneration in large scales.

\footnotetext{
*Corresponding author: fatih.seyis@erdogan.edu.tr
} 
Afterward, a range of further experiments on stevia tissue culture are carried out such as application of shoot primordial explants (Motomu et al., 1994), shoot apex, nodal and leaf explants (Sivaram \& Mukundan, 2003), nodal explants (Rafiq et al., 2007), leaf direct organogenesis (Sreedhar et al., 2008), nodal explants (Ahmed and Salahin, 2007; Mousumi, 2008), Stevia rhizogenesis (Tamura et al., 1984b; Ferreria and Handro (1988), rooting (Sivaram and Mukondan, 2003) and duse of diffrent plant hormones (Rafiq et al., 2007; Ahmed and Salahin, 2007; Sreedhar et al., 2008; Ibrahim et al., 2008 and Ibrahim et al., 2008) But, Pourvi et al. (2009) has shown MS medium with 0.5 $\mathrm{mg} / \mathrm{l}$ NAA as the most efficient medium for stevia rooting.

It is known that plantlet produced through stem cutting are unstability, therefore micropropagation of Stevia may overcome many of the limitations associated with conventional method and this can be used for rapid multiplication.

This study aimed to in vitro multiplication of leaf, stem and root explants of two Stevia (Stevia rebaudiana Bertoni) genotypes in different tissue culture media for multiplication.

\section{MATERIALS AND METHODS}

The present study was conducted in the tissue culture laboratory of the Faculty of Agriculture and Natural Sciences, Recep Tayyip Erdoğan University. Two Stevia ( $S$. rebaudiana Bertoni) genotypes originated from Bafra/Turkey and China were used as seed material.

\section{Sterilization}

The surface sterilization of Stevia ( $S$. rebaudiana Bertoni) seeds washed one as follows: the seeds were first washed $10 \mathrm{~min}$ under a flowing tap. Then the seeds were sterilized with alcohol (ethanol $70 \%$ ) for 2 minutes, then washed three times with distilled water. Further, the same seeds were sterilized with $\mathrm{NaOCl}(3 \%)$ for 5 minutes and washed again with sterilized water up to cleaned from $\mathrm{NaOCl} .10$ sterilized seeds were transferred then to Magenta caps containing pure MS media. Each magenta cap was wrapped with aluminum folia and incubed in a growth chamber programmed with an 16/8 $\mathrm{h}$ light/dark cycle and $25 \pm 2{ }^{\circ} \mathrm{C}$ temperature (Fatima and Khan, 2010).

The tissue culture media used for the multiplication of stevia seeds are listed in Table 1.

Table 1. Tissue culture media

\begin{tabular}{l}
\hline Pure MS \\
\hline $\mathrm{MS}+1 \mathrm{mg} / \mathrm{lt} \mathrm{BAP}+2 \%$ sugar \\
\hline $\mathrm{MS}+1,5 \mathrm{mg} / \mathrm{lt} \mathrm{BAP}+2 \%$ sugar \\
\hline $\mathrm{pH}=5.7$ \\
\hline
\end{tabular}

Explants (root, stem, leaf) were obtained from 15 days old plantlets. $1 \mathrm{~cm}$ long explants were transferred to petri dishes (10 explants/petri dish). For regeneration the petri dishes were incubed in a growth chamber programmed with an $16 / 8 \mathrm{~h}$ light/dark cycle and $25 \pm 2{ }^{\circ} \mathrm{C}$ temperature. Developed shoots were transferred in tissue culture media containing $1 \mathrm{mg} / \mathrm{L}$ IAA for rooting. Rooted plantlets were transferred first to sterilized soil and stayed for 15 days in a pre-acclimatization room. After that, they were transferred to outer conditions. Obtained values were calculated using Excel.

\section{RESULTS AND DISCUSSION}

The highest shoot regeneration was obtained in both genotypes in stem explants placed in tissue culture media $\mathrm{MS}+1,5 \mathrm{mg} / \mathrm{L}$ BAP. The lowest shoot regeneration was obtained from leaf explants (Table 2, Fig.1) in both genotypes cultiavted on pure MS culture media. 
Table 2. Regeneration frequencies and standard deviation values of Stevia genotypes obtained from different explants

\begin{tabular}{lllll}
\hline Plant material & Tissue culture media & Stem explant & Root explant & Leaf explant \\
\hline \multirow{2}{*}{ Bafra Material } & $\mathrm{MS}$ & $1,66 \pm 0,57$ & $2,33 \pm 0,5$ & $0,33 \pm 0,5$ \\
\cline { 2 - 5 } & $\mathrm{MS}+1 \mathrm{mg} / \mathrm{lt} \mathrm{BAP}$ & $6,0 \pm 2,6$ & $4,0 \pm 2,6$ & $3,0 \pm 1,0$ \\
\cline { 2 - 5 } & $\mathrm{MS}+1,5 \mathrm{mg} / \mathrm{lt} \mathrm{BAP}$ & $11,33 \pm 2,08$ & $8,0 \pm 2,0$ & $3,0 \pm 1,0$ \\
\hline \multirow{2}{*}{ Chinese } & $\mathrm{MS}$ & $3,33 \pm 1,1$ & $0,66 \pm 0,1$ & $2,33 \pm 1,00$ \\
\cline { 2 - 5 } Material & $\mathrm{MS}+1 \mathrm{mg} / \mathrm{lt} \mathrm{BAP}$ & $5,0 \pm 1,0$ & $7,33 \pm 2,08$ & $2,66 \pm 0,5$ \\
\cline { 2 - 5 } & $\mathrm{MS}+1,5 \mathrm{mg} / \mathrm{lt} \mathrm{BAP}$ & $24,0 \pm 3,6$ & $12,3 \pm 2,5$ & $3,33 \pm 1,00$ \\
\end{tabular}

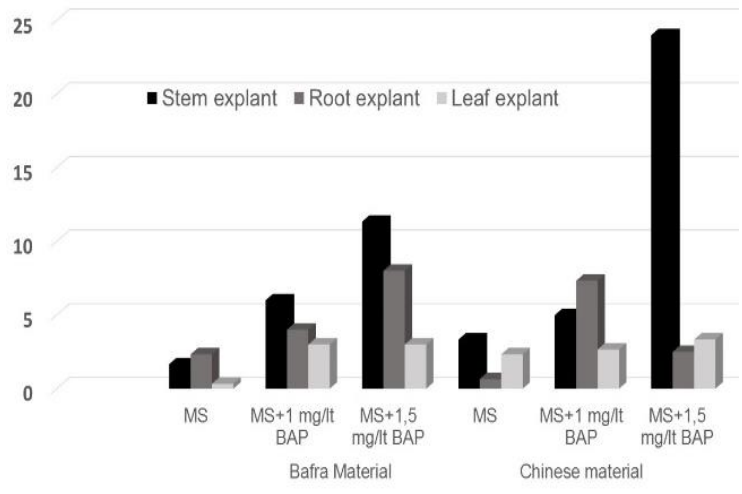

Fig. 1. Regeneration frequencies of Stevia genotypes from different explants

A clear tissue culture media, genotype and explant interaction have been seen in this experiment (Fig. 1). In every genotype obtained plants increased from explant type up to tissue culture media.

In Table 3 and Fig. 2 the number of rooted plants obtained from different explant after transfer to rooting medium were given. The highest number of rooting plants in both genotypes was developed from stem explants $(80 \%$ in Bafra material and $85,7 \%$ in Chinese material). The number of obtained and rooted plants originating from root and leaf explants were remarkably lower in both genotypes $(50 \%$ and $0 \%$ in Bafra material and 62,5 and 25\%) in Chinese material.
Table 3. Number of plants obtained from explants transferred to rooting medium

\begin{tabular}{|c|c|c|c|c|c|}
\hline Plant material & Media & Explant & $\begin{array}{l}\text { Nr. transferred } \\
\text { plants }\end{array}$ & $\begin{array}{l}\mathrm{Nr} \text {. of } \\
\text { rooted plants }\end{array}$ & $\begin{array}{l}\text { Obtained } \\
\text { plants (\%) }\end{array}$ \\
\hline \multirow[t]{3}{*}{ Bafra Material } & & Stem & 20 & 16 & 80 \\
\hline & & Root & 4 & 2 & 50 \\
\hline & & Leaf & 1 & 0 & 0 \\
\hline \multirow{4}{*}{$\begin{array}{l}\text { Chinese } \\
\text { Material }\end{array}$} & MS+1 & & & & \\
\hline & $\mathrm{mg} / \mathrm{lt} \mathrm{IAA}$ & Stem & 28 & 24 & 85,7 \\
\hline & & Root & 8 & 5 & 62,5 \\
\hline & & Leaf & 4 & 1 & 25 \\
\hline
\end{tabular}

Taken explants and obtained plants from both genotypes in vitro can be seen in Fig. 3 and Fig. 4.

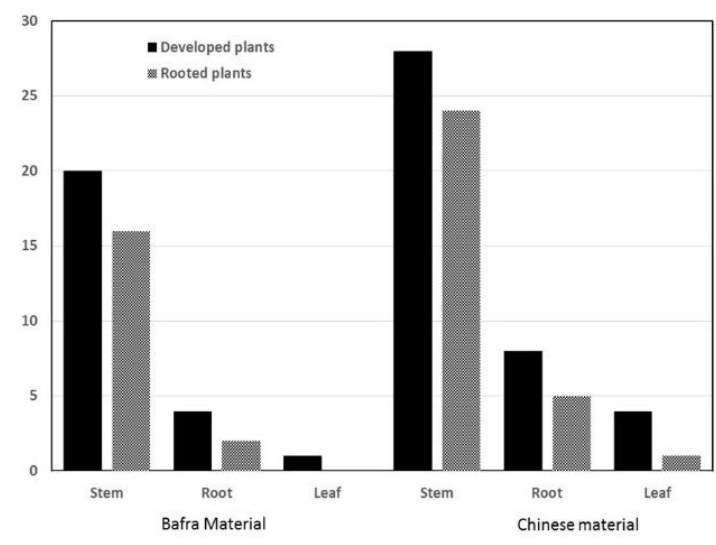

Fig. 2. Number of plants obtained from plantlets originating from different explants transferred to rooting medium

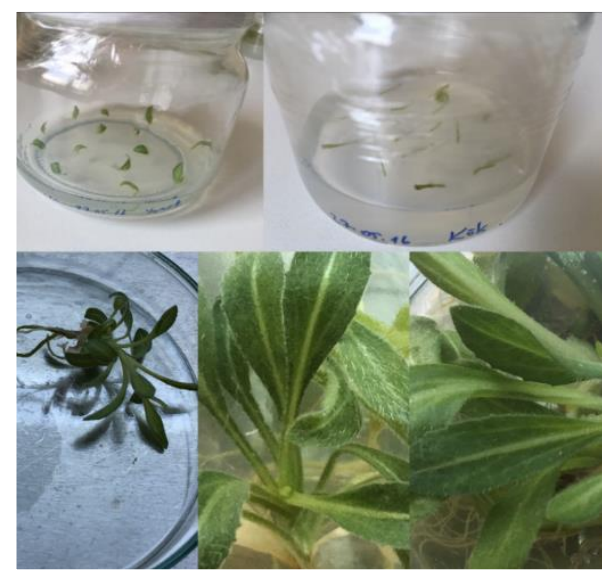

Fig. 3. Explants (3a, 3b) and obtained plants (3c, 3d) from Chinese material 


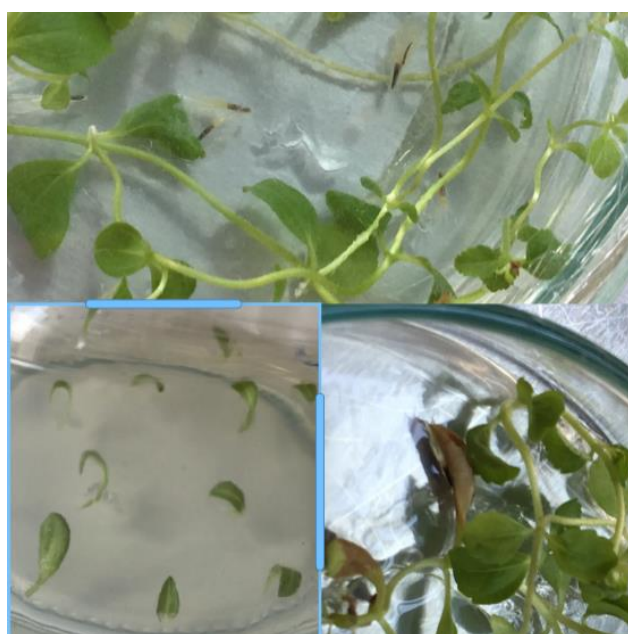

Fig. 4. Explants (4b) and obtained plants $(4 a, 4 c)$ from Bafra material

Stevia large-scale production is needed for industrial applications. Seeds of Stevia show a very low germination percentage (Felippe and Lucas, 1971; Toffler and Orio, 1981), and vegetative propagation through cuttings is limited by the small number of individuals (Sakaguchi and Kan, 1982). Tissue culture is the only rapid process for the mass propagation of Stevia.

Biotechnological approaches such as in vitro plant tissue culture methods have been applied for the multiplication of stevia all over the world via organogenesis or embryogenesis from different explants for instance axillary shoots, leaves (Ferreira and Handro, 1988), stem tips (Tamura et al., 1984a), nodal segments (Ahmed et al., 2007), suspension cultures (Ferreira and Handro, 1988) and anthers (Flachsland and Mroginski, 1966) and stems (Miyagawa et al., 1984).

The induction of direct shoot regeneration depends on the nature of the plant organ from which the explant was derived and is highly dependent on plant (George, 1993). In our study, the number of obtained and rooted plants in every genotype using different explants was different.

We found that the stevia plant was able to multiplicate using different explants. It can be concluded that the investigated materials should be efficiently multiplicated by using the stem explants.

\section{CONCLUSION}

In vitro propagation can be considered an important alternative to conventional propagation and breeding procedures for $S$. rebaudiana which is both an industrially and medicinally important herb. The explants and plant growth regulators levels have significant impact on accelerated micropropagation of Stevia to regenerate, genetically true to the type propagules.

The success of in vitro culture depends mainly on the growth conditions of the source material, medium composition, culture conditions and on the genotypes of donor plants (Tiwari et al., 2013). In our case the Chinese genotype showed higher regeneration capacity compared with Bafra material.

Although present results are promising, only two genotypes were used in this study. Therefore to improve this herb's potential as a crop by developing improved varieties with commercially significant yield. there is a need for further improvement, research and development to be carried out.

\section{REFERENCES}

Ahmed, B., Salahin, M., Karim, R., Razvy, M.A., Hannan, M.M., Sultana, R., Hossain and Islam, MR. 2007. An Efficient Method for in vitro Clonal Propagation of a Newly Introduced Sweetener Plant (Stevia rebaudiana Bertoni.) in Bangladesh. AmericanEurasian Journal of Scientific Research, 2 (2): 121-125.

Ahmed, M.B. and Salahin M. 2007. An efficient method for in vitro clonal propagation of a newly introduced sweetener plant Stevia rebaudiana in Bangladesh. American Journal of Scientific Research, 2(2): 121-125. 
Brandle, J.E. and Rosa, N. 1992. Heritability for yield, leaf:stem ratio and stevioside content estimated from landrace cultivar of Stevia rebaudiana . Can. J. Plant Sci. 72: 1263-1266.

Debnath, M. 2008. Clonal propagation and antimicrobial activity of an endemic medicinal pant Stevia rebaudiana. J. of Medicinal Plants Research. 2, 045- 051.

Fatima, A. and Khan, S.J. 2010. Some factors affecting the in vitro growth of Stevia rebaudiana Bertoni. Iranian Journal of Plant Physiology 1 (2): 6168.

Felippe, G.M. and Lucas, N.M.C. 1971. Estudo da viabilidade dos frutos de Stevia rebaudiana Bert. Hoehnea 1:95 105.

Ferreira. C.M. and Handro W. 1988. Micropropagation of Stevia rebaudiana through leaf explants from adult plants. Planta Medica. 54 (2): 157-160.

Flachsland, E. and Mroginski L. 1966. Regeneration of plants from anthers of Stevia rebaudiana Bertoni (Compositae) cultivated in vitro. Biocell. 20: 87-90.

George E.F. 1993. Plant propagation by tissue culture.Part - I. The Technology Exgetics Ltd., U.K.

Ghuari, E.G., A. Fatima, S. Ghani and N. Shafi. 2009. Micropropagation and antimicrobial activity of an exotic sweetener plant (Stevia rebaudiana Bertoni). Pak. J. Biochem. Mol. Biol., 42(2): 53-56.

Ibrahim, A., Mahmoud, I.N., Berlanti, R. and Mohammed M. 2008. Plant growth regulators affecting in vitro cultivation of Stevia rebaudiana. Sugar Technology, 10(3): 254-259.

Katayama, O., Sumida, T., Hayashi, K. and Mitsuhashi, H. 1976. Safety of stevioside. In

Applicability of Stevia and Data on Research and Development, Isu Co. Ltd., Tokyo, pp. 225-281.

Kinghorn, D.A. 2002. Overview. In: Kinghorn, A.D. (Ed.), Stevia the Genus Stevia (Medicinal and Aromatic Plants -
Industrial Profiles). Taylor \& Francis/CRC Press, New York/London, UK, pp. 1-17.

Lu, C. 1993. The use of Thidiazuran in tissue culture. In vitro cell development. Biol. Plant., 29: 92-96.

Miyagawa, H. and Fujioka, N. 1986. Studies on the tissue culture of Stevia rebaudiana and its components: II. Induction of shoot primordia. Planta Medica. 4: 321-323.

Motomu, A., Shigeoka, T., Koizumi, Y., and Kawamura, M. 1994. Mass propagation of shoots of Stevia rebaudiana using a large scale bioreactor. Plant Cell Reports, 13 (3-4): 180-183.

Mousumi, D. 2008. Clonal propagation and antimicrobial activity of an endemic medicinal plant Stevia rebaudiana. Journal of Medicinal Plants Research, 2(2): 045-051.

Pourvi, J., Kachhwaha, S. and Kothari, SL. 2009. Improved micropropagation protocol and enhancement in biomass and chlorophyll content in Stevia rebaudiana (Bert.) Bertoni by using high copper levels in the culture medium. Scientia Horticulturae, 119(3): 315-319.

Rafiq, M., Muhammad, UD., Sher, MM., Naqvi, HA and Qarshi, IA. 2007. In Vitro Clonal Propagation and Biochemical Analysis of Field Established Stevia rebaudiana Bertoni. Pakistanian Journal of Botany, 39(7): 2467-2474.

Sakaguchi, M , and Kan, T. 1982. Japanese researches on Stevia rebaudiana (Bert.) Bertoni and stevioside. CiCult 34: 235248.

Sivaram, L. and Mukundan, U. 2003. In vitro culture studies on Stevia rebaudiana. In vitro cell and developmental Biolology in Plant, 39: 520-523.

Sreedhar, R.V., Venkatachalam, R., Thimmaraju, N., Bhagyalakshmi, MS., Narayan, L. and Ravishankar, GA. 2008. Direct organogenesis from leaf explants of Stevia rebaudiana and 
cultivation in bioreactor. Biologia Plantarum, 52 (2): 355-360.

Strauss,S. 1995. The perfect sweetener? Technol. Rev. 98: 1820.

Tamura,Y., Nakamura,S., Fukui,H. and Tabata, M. 1984a. Comparison of Stevia plants grown from seeds, cuttings and stem tip cultures for growth and sweet diterpene glycosides. Plant Cell Rep. 3 : 180182.

Tamura, Y., Nakamura, S., Fukui, H. and Tabata M. 1984b. Clonal propagation of Stevia rebaudiana Bertoni by stem-tip culture Plant Cell Reports 3: 183.

Tiwari, S., Arnold, R., Saxena, A., Mishra, R.M., Tiwarii A.S., Rajak, A. and Singh, P. 2013. Studies on rapid micropropagation of Stevia rebaudiana Bertoni: A natural sweetener. Int. J. of Pharm. \& Life Sci. (IJPLS), Vol. 4, Issue 5: May: 2013, 2667-2671

Toffler F. and Orio O.A. 1981 . Acceni sulla pin ata tropicale 'Kaa - he - e' ou 'erba dolce'. Rev. Soc. Sci. Aliment 4: 225 230

Yang, Y.W., Y.I. Hsing and W.C. Chang. 1981. Clonal propagation of Stevia rebaudiana Bertoni through axillary shoot proliferation In vitro. Bot. Bull. Academia, 22: 57-62. 